Agropedology 2016, 26 (02), 132-148

\title{
Effect of Phosphorous Application on Uptake, Yield and Fertilizer Use Efficiency under Rice-Rice and Rice-Sunflower Systems in High P Soils
}

\author{
A. Srinivas, P.Surendra Babu, A.Madhavi, G.E.C.H.Vidyasagar \\ and G.R. Maruthi Sankar* \\ Professor Jayashankar Telangana State Agricultural University, Rajendranagar, \\ Hyderabad-500030, Telangana, India \\ *World Bank-Sujala Project, Department of Soil Science and Agricultural Chemistry, \\ University of Agricultural Sciences, GKVK, Bangalore-560065, Karnataka, India.
}

\begin{abstract}
Field experiments on high P soils were conducted during 2009-10 and 2010-11 to assess (i) P fertilizer requirement and (ii) $\mathrm{P}$ fertilizer use efficiency using ${ }^{32} \mathrm{P}$ isotope in rice-rice and rice-sunflower ( $\mathrm{rabi}$ ) systems. Four treatments in kharif (T1: 100\%, T2: 75\%, T3: 50\% and T4: 25\%) recommended dose of phosphorus (RDP) and three treatments in rabi (T1: 100\%, T2: 75\%, T3: 50\% RDP) were tested. A uniform dose of 100\% recommended $48 \mathrm{~kg} \mathrm{ha}^{-1}$ of N and $24 \mathrm{~kg} \mathrm{ha}^{-1}$ of K were applied along with $\mathrm{P}$ treatments. The P removal both grain and straw by both crops under ricerice system was at par with 100 and $75 \%$ RDP. The percent P utilization in entire system revealed that $75 \%$ RDP gave better utilization of applied P to a tune of $26 \%$ compared to $22 \%$ realized by $100 \%$ RDP in each crop. Similar trend of P removal by rice and sunflower seeds in rice-sunflower system was observed. Percent $\mathrm{P}$ utilization in both crops was $24.5 \%$ under $100 \%$ RDP and $27.2 \%$ under $75 \%$ RDP. The study clearly indicated $25 \%$ reduction in P fertilization for both cropping systems in high P soils.
\end{abstract}

Keywords: Fertilizer $\mathrm{P},{ }^{32} \mathrm{P}$ isotope, $\mathrm{P}$ uptake, fertilizer use efficiency, rice-rice, rice-sunflower

\section{Introduction}

The importance of phosphorus fertilizers in crop production is undisputable. Concerted efforts were made to enhance the use efficiency of not only $\mathrm{P}$ but also of other costly nutrient inputs to economize cost of cultivation and conserve resources. Phosphatic fertilizers are known to be highly reactive with the soil and get fixed in upper layers with efficiency never exceeding beyond 20 to $25 \%$. The continuous or indiscriminate use of $\mathrm{P}$ fertilizer would increase $\mathrm{P}$ accumulation in top layers of soils. The accumulation of $\mathrm{P}$ in soils would be a continuous phenomenon as long as fertilizers are used. Deb (2009) indicated that unless P-fixing sites are saturated to certain degree, availability of native and applied $\mathrm{P}$ will not increase. Therefore, extent of P-accumulation is also important to realize its implications. The occurrence of high $\mathrm{P}$ soil will have implication of (a) saving $P$ fertilizer without sacrificing

\footnotetext{
*Corresponding Author Email: gmsankar2009@gmail.com
}

current level of production; and (b) interference with availability of other nutrients in soil. Singh et al., (1996) reported that sunflower seed yield increased due to application of $80 \mathrm{mg}$ P. In medium P soils, Rao et al., (1989) tried different $\mathrm{P}$ levels in rice-based system. They reported that rice yield increased due to residual effects at 80 and 120 $\mathrm{kg} \mathrm{P}_{2} \mathrm{O}_{5} \mathrm{ha}^{-1}$.

Choudhary and Thakur (2007) observed that P dose could be skipped in either of any crop or reduced to $50 \%$ under rice-wheat sequence. However, it was better to skip P application in rice wet season than wheat dry season as well as nutrient uptake point of view. Patel et al., (2012) reported that rice responded significantly to $P$ application with respect to grain yield. The uptake of $\mathrm{P}$ by rice and $\mathrm{P}$ in soils after rice harvest was recorded higher if $\mathrm{P}$ application was made through press-mud biocompost compared to single super phosphate (SSP). Application of $\mathrm{P}$ to rice significantly increased millable cane yield and sugarcane equivalent of rice-sugarcane, total $\mathrm{P}$ uptake by sugarcane and $\mathrm{P}$ status of 
soils after harvest of sugarcane. Application of $40 \mathrm{~kg} \mathrm{P}_{2} \mathrm{O}_{5} \mathrm{ha}^{-1}$ produced $858 \mathrm{~kg} \mathrm{ha}^{-1}$ yield of cowpea, which was 24.2 and $9.8 \%$ higher over control and $20 \mathrm{~kg} \mathrm{P}_{2} \mathrm{O}_{5} \mathrm{ha}^{-1}$ respectively (Jat etal., 2013).

Wallace et al., (1977) studied influence of P on zinc, iron, manganese and copper uptake and found that at high $\mathrm{pH}$, increasing solution $\mathrm{P}$ decreased leaf, stem, and root concentration of $\mathrm{Zn}, \mathrm{Mn}$ and $\mathrm{Cu}$ in soybean. They observed a decrease in iron content of roots but not in leaves and stem, while in contrast at low $\mathrm{pH}$, increased $\mathrm{P}$ resulted in more $\mathrm{Zn}$, $\mathrm{Mn}$ and $\mathrm{Cu}$ but less Fe in leaves, stem, and roots of soybean. Agrawal and Verma (1998) observed an increase in P content $(0.33 \%)$ and uptake $\left(18.5 \mathrm{~kg} \mathrm{ha}^{-1}\right)$ by sunflower up to $90 \mathrm{~kg}$ $\mathrm{P}_{2} \mathrm{O}_{5}$ application. Gill et al., (2004) reported that P@100 mg $\mathrm{kg}^{-1}$ significantly increased $\mathrm{P}$ in Brassica and sunflower. Bogdanovic et al., (1999) concluded that a high soil $\mathrm{P}$ reduced $\mathrm{Zn}$ availability. The content of $\mathrm{Zn}$ in stalks and leaves was significantly lower in treatments of $\mathrm{P}$ than control due to $\mathrm{P} \times \mathrm{Zn}$ interaction.

Highest grain yield of cowpea was obtained with 20 and $5 \mathrm{~kg} \mathrm{Znha}{ }^{-1}$, while haulm occurred at P@60kg and Zn@ $2.5 \mathrm{~kg} \mathrm{ha}^{-1}$ (Oseni 2009). Higher $\mathrm{P}$ availability in soil significantly decreased $\mathrm{Mn}, \mathrm{Zn}$ and $\mathrm{Cu}$ in eight barley cultivars. Total zinc uptake by root plus shoot decreased sharply when Olsen $\mathrm{P}$ at harvest was $>15 \mathrm{mg} \mathrm{P} \mathrm{kg}^{-1}$ soil (Manchanda et al. 2012). The present investigation was taken up to study: (i) P fertilizer requirement to rice-rice and rice-sunflower systems; and (ii) $\mathrm{P}$ fertilizer use efficiency using ${ }^{32} \mathrm{P}$ isotope in rice-rice and rice-sunflower systems on a high P soil.

\section{Materials and Methods}

The present study was conducted in Hyderabad located at $18^{\circ} 95^{\prime}$ and $77^{\circ} 85^{\prime}$ and at an altitude of $542.6 \mathrm{~m}$ above mean sea level. Hyderabad falls under semi-arid climate with mean annual rainfall of $800 \mathrm{~mm}$. The soils of experimental plots of high available $\mathrm{P}$ were collected prior to the selection of site for experimentation. Standard methods were followed for preparing soil samples for analysis.

The experimental area was divided into 2 fields and designated as Field-I and Field-II. Each field was further divided into two parts and designated as Plot-1 and Plot-2 in
Field-I and Plot-3 and Plot-4 in Field-II. Plot-1 of field-1 was used for rice-rice and plot-2 was used for rice-sunflower cropping system during 2009-10. Thus during 2009-10, rice was raised in plot-1 and plot-2 in kharif, whereas rice was raised in plot- 1 and sunflower was raised in plot- 2 in $\mathrm{rabi}$.

During 2010-11, Field-II was used to repeat the experiment of rice-rice and rice-sunflower system as a second year study in plot-3 and plot-4. Four treatments in kharif (T1: 100\%, T2: 75\%, T3: 50\% and T4: 25\% RDP) and three treatments in rabi (T1: 100\%, T2: 75\%, T3: 50\% RDP) were tested. A uniform dose of $100 \%$ recommended $48 \mathrm{~kg}$ ha ${ }^{1}$ of $\mathrm{N}$ and $24 \mathrm{~kg} \mathrm{ha}^{-1}$ of $\mathrm{K}$ were applied along with $\mathrm{P}$ treatments. ${ }^{32} \mathrm{P} 0.25 \mathrm{mCi} \mathrm{g}^{-1} \mathrm{P}_{2} \mathrm{O}_{5}$ was used to tag $\mathrm{P}$ during kharif and rabi crops. During kharif, standard micro-plots were made on one side of a treated plot and $\mathrm{P}^{32}$ was applied. During rabi, where kharif plot was divided into 3 sub-plots (to impose rabi $\mathrm{P}$ treatments), micro-plots in these sub-plots were made on opposite side of what has been done in kharif.

Each experimental plot had a net plot size of $13.2 \mathrm{~m}$ x 5.4 m in Field-1 during 2009-10 and Field-2 during 201011. Each plot included a micro-plot at south-west corner. Paddy seed (var. BPT-5204) was used for raising nursery after treating with carbendazim @ $3 \mathrm{~g} \mathrm{~kg}^{-1}$ seed. Recommended N, P and K for nursery was applied before sowing. Recommended N@120kgha ${ }^{-1}, \mathrm{P} @ 60 \mathrm{~kg} \mathrm{ha}^{-1}, \mathrm{~K} @$ $40 \mathrm{~kg} \mathrm{ha}^{-1}$ were applied in both kharif and rabi seasons, while zinc sulphate@, $50 \mathrm{~kg} \mathrm{ha}^{-1}$ was applied only in kharif season. Nitrogen was applied in 3 equal splits at transplanting, tillering and panicle initiation stages, while $\mathrm{P}, \mathrm{K}$ and Zinc Sulphate were applied as basal.

Irrigation was given to maintain $2 \mathrm{~cm}$ height water layer in the field. Two manual weedings were done at 25 and 45 days after transplanting. Required quantity of $\mathrm{P}$ fertilizer as per treatment in micro-plots for each season were calculated. Based on fertilizer quantity, ${ }^{32} \mathrm{P}$ isotope was obtained from Bhabha Atomic Research Center, Mumbai and was tagged physically by preparing $\mathrm{P}$ solution according to the treatments. In micro-plots, ${ }^{32} \mathrm{P}$ tagged $\mathrm{P}_{2} \mathrm{O}_{5}$ was applied one week after transplanting. Plant samples of ${ }^{32} \mathrm{P}$ tagged $\mathrm{P}_{2} \mathrm{O}_{5}$ applied in all micro-plots of rice were collected from each plot at maximum tillering stage. Plant samples of grain and straw at harvest were collected from each main plot from 
both fields. Post-harvest soil samples (0-15 cm depth) were collected to know the P status.

Cultivation details for rabi rice (in plot-1 of field-I and plot-3 offield-II)

In order to study the direct and residual effect of $\mathrm{P}$ in rice-rice system, rice was taken in Plot-1 of Field-I and Plot3 of Field-II during 2009-10 and 2010-11 respectively. Each treated plot of kharif was manually worked out and divided into 3 equal parts and rabi treatments were imposed randomly in each plot. The micro plots were made on opposite side of the plot in contrast to earlier kharif micro plot. Recommended fertilizer dose and ${ }^{32} \mathrm{P} @ 0.25 \mathrm{mCi} \mathrm{g}^{-1}$ $\mathrm{P}_{2} \mathrm{O}_{5}$ were applied similar to kharif. The plants in micro-plots were sampled at maximum tillering stage and grain and straw samples were collected at the harvest stage.

Cultivation details for rabi sunflower (in plot-2 of field-I and plot-4 offield-II)

Sunflower (var. DRSF-108) was raised during rabi of 2009-10 and 2010-11 in Plot-2 of Field-I and Plot-4 of Field-II respectively after kharif rice. The field with different plots of kharif was prepared manually to achieve optimum tilth. Seed treatment with imidacloprid @ $5 \mathrm{~g} \mathrm{~kg}^{-1}$ and carbendazim $1 \mathrm{~g} \mathrm{~kg}^{-1}$ seed was done. Recommended doses of $\mathrm{N} @ 60 \mathrm{~kg} \mathrm{ha}^{-1}, \mathrm{P} @ 60 \mathrm{kgha}^{-1}$ and K@3 $30 \mathrm{kgha}^{-1}$ were applied to all plots. $\mathrm{P}^{32}$ was applied in micro-plots at 20 DAS. The plots were maintained weed free during entire season. Irrigation was given at 15-20 days interval coinciding with critical stages (bud initiation, flowering and seed setting) of crop growth. Plant samples from micro-plots were collected at bud initiation stage. Sunflower seed and stalk samples were collected at harvest. Soil samples after harvest of $\mathrm{rabi}$ rice and sunflower were collected and analyzed for available $\mathrm{P}_{2} \mathrm{O}_{5}$. Soil and plant analysis

The standard procedures of soil chemical analysis of $\mathrm{pH}$, electrical conductivity $\left(\mathrm{dS} \mathrm{m}^{-1}\right)$ were followed (Jackson,
1973). The organic carbon (\%) by rapid titration method (Walkley and Black, 1934), available N (Subbaiah and Asija, 1956) and $P$ was extracted by using Olsen's extractant (Olsen et al., 1954). Available $\mathrm{K}$ was determined as discussed by Jackson (1973). Available Zn ( $\mathrm{mg} \mathrm{kg}^{-1}$ ) was estimated by atomic absorption spectrophotometer employing the method given by Lindsay and Norvell (1978). Based on the analysis, the soil had a $\mathrm{pH}$ of 7.45 , bulk density of $1.55 \mathrm{mg} \mathrm{m}^{-1}$ and electrical conductivity of $0.34 \mathrm{dsm}^{-1}$, organic carbon of $0.82 \%$, N of $282 \mathrm{~kg} \mathrm{ha}^{-1}, \mathrm{P}_{2} \mathrm{O}_{5}$ of $126 \mathrm{~kg} \mathrm{ha}^{-1}, \mathrm{~K}_{2} \mathrm{O}$ of $302 \mathrm{~kg} \mathrm{ha}$ ${ }^{1}$ and DTPA-Zn of $3.1 \mathrm{mg} \mathrm{kg}^{-1}$.

The oven dried plant samples were ground in Wiley mill and used for digestion as per the procedure given by Shaw (1959) using tri acid mixture of $\mathrm{HNO}_{3}: \mathrm{H}_{2} \mathrm{SO}_{4}: \mathrm{HClO}_{4}$ in 9:4:1 ratio for non-radio isotope tagged plant samples. For radio assay, analysis was carried out by following procedures given by IAEA (1976). One gram of powdered plant sample was weighed into silica crucible and charred on an electrical heater as pre-ignition treatment. Though, volatalization losses of $\mathrm{P}$ at high temperatures above $300{ }^{\circ} \mathrm{C}$ was low, magnesium nitrate was added at various concentrations to reduce $\mathrm{P}$ losses. Later, it was ashed at $823^{\circ} \mathrm{K}$ in a muffle furnace for 2-3 hours. The contents of ash in crucibles were digested in $5 \mathrm{ml}$ of 1:1 $\mathrm{HNO}_{3}$ and heated gently on a sand bath. The contents were filtered using $1: 10 \mathrm{HNO}_{3}$ and volume was made up to $25 \mathrm{ml}$. Phosphorus was determined by modified vanadomolybdo phosphoric acid yellow colour method (Jackson, 1973). One $\mathrm{ml}$ aliquot of above solution was pipetted into a $25 \mathrm{ml}$ volumetric flask and colour was developed with Barton's reagent. The colour intensity was read on a Klett Summerson colorimeter using blue filter (470 $\mathrm{nm}$ ). For radio assay, $5 \mathrm{ml}$ of above aliquot was taken into small micro beakers and dried under infra red lamp. Using GM counter (Model RCS 4027A), ${ }^{32} \mathrm{P}$ activity of dried residue in micro beakers was counted along with fertilizer standards. The calculations for radio assaying were done as below:

[Counts in $5 \mathrm{ml}$ of extractant] $\mathrm{x}$ [ $\mathrm{ml}$ required $\mathrm{mg} \mathrm{P}^{-1}$ ]

Quantity of extractant $x$ time of counting (seconds) 


Specific activity in plant sample
Specific activity in fertilizer

The standard analysis of variance of Randomized Block Design was carried out to test the $P$ fertilizer effects on different parameters in kharif and rabi seasons.

\section{Results and Discussion}

Rice-Rice system

\section{Effect of P doses on nutrient content and uptake of P in kharif} rice grain

The $\mathrm{P}$ content in kharif rice grain ranged from 0.33 to $0.35 \%$ in different treatments. Application of different levels of $\mathrm{P}$ fertilizer did not influence the $\mathrm{P}$ content of rice grain in individual years and also when pooled over years as given in table 1. The P-uptake by kharif rice grain was significantly influenced by different rates of $\mathrm{P}$ fertilizer. The mean P uptake decreased gradually from 19.97 to 17.40 $\mathrm{kg} \mathrm{ha}^{-1}$ with a decrease in P doses. Application of 100 and
$75 \% \mathrm{RDF}$ were at par, while 25 and $50 \%$ RDP differed significantly in influencing the $\mathrm{P}$ uptake in rice grain.

Effect of $P$ doses on content and uptake of zinc in kharif rice grain

The zinc content of rice grain ranged from 21.26 to $24.77 \mathrm{mg} \mathrm{kg}^{-1}$ as P dose increased from 25 to $100 \%$ RDP (Table 1). However, lower doses of $\mathrm{P}$ gave significantly lower zinc content in rice grain compared to 75 and $100 \%$ RDP. The main effect of years and interaction of years and treatments on zinc content in grain were not significant. The zinc uptake by kharif rice grain was significantly affected by different rates of $\mathrm{P}$ applied to the crop. The mean zinc uptake ranged from 112 to $141 \mathrm{~g} \mathrm{ha}^{-1}$. Reduced dose of P @ 50 and $25 \%$ RDP gave significantly lower zinc uptake by rice grain compared to 75 and $100 \%$ RDP.

Table 1. Effect of fertilizer $P$ on content and uptake of $P$ and zinc in kharif rice grain under rice-rice system

\begin{tabular}{|c|c|c|c|c|c|c|}
\hline Treatments & 2009 & 2010 & Mean & 2009 & 2010 & Mean \\
\hline P content $(\%)$ & & \multicolumn{5}{|c|}{ Zinc content $\left(\mathrm{mg} \mathrm{kg}^{-1}\right)$} \\
\hline $100 \%$ RDP & 0.35 & 0.35 & 0.35 & 24.60 & 24.95 & 24.77 \\
\hline $75 \%$ RDP & 0.35 & 0.34 & 0.35 & 24.54 & 24.24 & 24.39 \\
\hline $50 \%$ RDP & 0.34 & 0.33 & 0.34 & 22.29 & 22.46 & 22.38 \\
\hline $25 \%$ RDP & 0.33 & 0.33 & 0.33 & 20.98 & 21.53 & 21.26 \\
\hline \multirow[t]{2}{*}{ Mean } & 0.34 & 0.34 & & 23.10 & 23.29 & \\
\hline & $Y$ & $T$ & $Y \times T$ & $Y$ & $T$ & $Y \times T$ \\
\hline $\operatorname{SEm}( \pm)$ & 0.013 & 0.012 & 0.024 & 0.34 & 0.48 & 0.68 \\
\hline $\operatorname{LSD}(p<0.05)$ & $N S$ & $N S$ & $N S$ & $N S$ & 1.40 & $N S$ \\
\hline P uptake $\left(\mathrm{kg} \mathrm{ha}^{-1}\right)$ & & \multicolumn{5}{|c|}{ Zinc uptake $\left(\mathrm{g} \mathrm{ha}^{-1}\right)$} \\
\hline $100 \%$ RDP & 19.81 & 20.12 & 19.97 & 138 & 142 & 140 \\
\hline $75 \%$ RDP & 19.72 & 19.81 & 19.76 & 141 & 141 & 141 \\
\hline $50 \% \mathrm{RDP}$ & 17.91 & 17.91 & 17.91 & 118 & 124 & 121 \\
\hline $25 \% \mathrm{RDP}$ & 17.33 & 17.47 & 17.40 & 110 & 114 & 112 \\
\hline \multirow[t]{2}{*}{ Mean } & 18.69 & 18.82 & & 127 & 130 & \\
\hline & $Y$ & $T$ & $Y \times T$ & $Y$ & $T$ & $Y \times T$ \\
\hline $\operatorname{SEm}( \pm)$ & 0.35 & 0.48 & 0.71 & 2.05 & 2.89 & 4.09 \\
\hline $\operatorname{LSD}(p<0.05)$ & $N S$ & 1.51 & $N S$ & $N S$ & 8.45 & $N S$ \\
\hline
\end{tabular}

$\mathrm{Y}:$ Years

$\mathrm{T}:$ Treatments

SEm : Standard error of mean

NS : Not significantLSD : Least significant difference 
Effect of $P$ on nutrient content and uptake of $P$ in kharif rice straw

The $\mathrm{P}$ content of kharif rice straw was not influenced due to different rates of $P$ and interaction of years and treatments as given in Table 2. The P content was in the range of 0.13 to $0.15 \%$ under different treatments. The $\mathrm{P}$ uptake by kharif rice straw was significantly affected by different levels of P. P @ 75 and 100\% RDP gave at par P uptake by rice straw but uptakes were significantly higher than that of 25 and $50 \%$ RDP.
Effect of $P$ doses on content and uptake of zinc in kharif rice straw

The zinc content in kharif rice straw was significantly influenced by P doses. Application @,25\% RDP gave lowest zinc content of $24.97 \mathrm{mg} \mathrm{kg}$ and was significantly lower than any other level of $\mathrm{P}$. The zinc content of rice straw was at par due to application of 100 and $75 \%$ RDP. The zinc uptake was significantly influenced by different rates of $\mathrm{P}$ (Table 2). The mean zinc uptake ranged from 174 to $175 \mathrm{mg} \mathrm{kg}^{-1}$ with application of 75 and $100 \% \mathrm{RDP}$ to the crop. Application of 50\% RDP gave zinc uptake of 155 $\mathrm{mg} \mathrm{kg}{ }^{-1}$ in kharif rice straw which was significantly higher compared to $25 \%$ RDP and slightly lower than 75 and $100 \%$ RDP application.

Table 2. Effect of fertilizer $\mathrm{P}$ on content and uptake of $\mathrm{P}$ and zinc in kharif rice straw under rice-rice system

\begin{tabular}{|c|c|c|c|c|c|c|}
\hline Treatments & 2009 & 2010 & Mean & 2009 & 2010 & Mean \\
\hline $\mathrm{P}$ content $(\%)$ & \multicolumn{6}{|c|}{ Zinc content $\left(\mathrm{mg} \mathrm{kg}^{-1}\right)$} \\
\hline $100 \%$ RDP & 0.15 & 0.15 & 0.15 & 29.27 & 29.92 & 29.59 \\
\hline $75 \% \mathrm{RDP}$ & 0.15 & 0.15 & 0.15 & 28.72 & 28.61 & 28.66 \\
\hline $50 \% \mathrm{RDP}$ & 0.13 & 0.13 & 0.13 & 27.44 & 27.63 & 27.54 \\
\hline $25 \% \mathrm{RDP}$ & 0.13 & 0.13 & 0.13 & 25.10 & 24.83 & 24.97 \\
\hline \multirow[t]{2}{*}{ Mean } & 0.14 & 0.14 & & 27.63 & 27.75 & \\
\hline & $Y$ & $T$ & $Y \times T$ & $Y$ & $T$ & $Y \times T$ \\
\hline SEm ( \pm ) & 0.004 & 0.006 & 0.008 & 0.50 & 0.71 & 1.00 \\
\hline $\operatorname{LSD}(p<0.05)$ & $N S$ & NS & $N S$ & NS & 2.04 & $N S$ \\
\hline P uptake $\left(\mathrm{kg} \mathrm{ha}^{-1}\right)$ & \multicolumn{6}{|c|}{ Zinc uptake $\left(\mathrm{g} \mathrm{ha}^{-1}\right)$} \\
\hline $100 \%$ RDP & 8.70 & 9.01 & 8.85 & 171 & 178 & 175 \\
\hline $75 \%$ RDP & 9.07 & 9.21 & 9.14 & 173 & 175 & 174 \\
\hline $50 \% \mathrm{RDP}$ & 7.33 & 7.58 & 7.46 & 152 & 157 & 155 \\
\hline $25 \% \mathrm{DP}$ & 6.88 & 7.02 & 6.95 & 131 & 132 & 132 \\
\hline \multirow[t]{2}{*}{ Mean } & 7.99 & 8.21 & & 157 & 161 & \\
\hline & $Y$ & $T$ & $Y \times T$ & $Y$ & $T$ & $Y \times T$ \\
\hline $\operatorname{SEm}( \pm)$ & 0.25 & 0.35 & 0.49 & 3 & 4 & 5 \\
\hline $\operatorname{LSD}(p<0.05)$ & $N S$ & 1.01 & $N S$ & NS & 11 & $N S$ \\
\hline
\end{tabular}

${ }^{32}$ P based P-use efficiency parameters of kharif rice

The percent $\mathrm{P}$ derived from fertilizer by kharif rice dry matter at maximum tillering stage was significantly influenced by different rates of P. Highest Pdff was observed with $100 \%$ RDP, while lowest was observed with $25 \%$ RDP application. The interaction effect of years and treatments on Pdff by rice dry matter was significant. Phosphorus application at different levels significantly affected the $\mathrm{P}$ utilization by rice at maximum tillering stage. It increased significantly from $22.36 \%$ with $100 \%$ RDP to $38.10 \%$ with $25 \%$ RDP. The interaction of years and treatments on $\mathrm{P}$ utilization by rice was significant. The decrease in fertilizer $P$ with increasing fertilizer dose may be due to high soil $\mathrm{P}$ in the experimental field. The mean fertilizer P uptake by rice dry matter was highest at $5.72 \mathrm{~kg} \mathrm{ha}^{-1}$ when fertilizer was applied (a) 100\% RDP and was higher than any reduced level. The soil P uptake by kharif rice at maximum tillering stage was 
significantly affected by different rates of $\mathrm{P}$. The lowest soil $\mathrm{P}$ uptake $\left(15.18 \mathrm{~kg} \mathrm{ha}^{-1)}\right.$ was attained with application of $25 \%$ RDP. Phosphorus application @ 50 to 100\% RDP gave at par soil $\mathrm{P}$ uptake by rice at maximum tillering stage.

\section{Nutrient content and uptake by rice grain during rabi}

The effects of reduced $\mathrm{P}$ levels on $\mathrm{P}$ content in rabi rice grain is given in table 3 . Application of $100 \%$ RDP gave maximum mean $\mathrm{P}$ content $(0.35 \%)$ in rice grain, while $50 \%$ RDP gave minimum mean $\mathrm{P}$ content of $0.34 \%$. The kharif residual effect on rabi rice grain $\mathrm{P}$ content was highest of $0.35 \%$ where crop received $100 \%$ RDP during kharif. It was significantly superior to other treatments. However, P content in rabi rice grain was significantly lower in $0.33 \%$ when soil received 25\% RDP in earlier kharif compared to other treatments.

The $\mathrm{P}$ uptake by rabi rice grain decreased significantly from 20.38 to $17.85 \mathrm{~kg} \mathrm{ha}^{-1}$ with $\mathrm{P}$ application from 50 to $100 \%$ RDP (Table 3 ). The $\mathrm{P}$ uptake by rabi rice grain was maximum when $100 \%$ RDP was applied in kharif and was on par with $75 \%$ RDP applied in kharif. The interaction of rabi $\mathrm{P}$ treatments and residual kharif $\mathrm{P}$ rates on $\mathrm{P}$ uptake by rabi rice grain was significant. The combination applied 75 and 100\% RDP with residual kharif P rates of 100 and $75 \%$ RDP gave highest $\mathrm{P}$ uptake in grain of rabi rice.

\section{Effect of P on content and uptake of zinc in rabi rice grain}

The effect of rabi $\mathrm{P}$ rates and different $\mathrm{P}$ rates in kharif on zinc content of rabi rice grain are given in table 3. Phosphorus application during rabi@50 to 100\% RDP significantly increased the zinc content of rice grain in the range of 19.76 to $24.71 \mathrm{mg} \mathrm{kg}^{-1}$. Different rates of P applied in kharif did not affect zinc content in rabi rice grain. However, there was a gradual decrease in zinc content of pooled rabi rice grain as $\mathrm{P}$ rates in kharif decreased. The interaction of rabi $\mathrm{P}$ rates and residual kharif rates on zinc content of rabi rice grain was significant. In general, rabi $\mathrm{P}$ rates of 75 and $100 \%$ RDP in combination with all residual kharif $\mathrm{P}$ rates gave significantly higher zinc content in rabi rice grain compared to $50 \%$ RDP of rabi + different levels of residual kharif $\mathrm{P}$ rates. The zinc uptake by rabi rice grain was significantly affected due to different rates of $P$ received in kharif. Highest zinc uptake of $136 \mathrm{~g} \mathrm{ha}^{-1}$ was observed in rabi rice grain when crop received $100 \% \mathrm{RDP}$ in kharif and was at par with 75\% RDP of kharif. The interaction effect of rabi treatments in conjunction with residual kharif $\mathrm{P}$ treatments was significant on zinc uptake by rabi rice grain.

Table 3. Effect of fertilizer $\mathrm{P}$ on content and uptake of $\mathrm{P}$ and zinc in rabi rice grain under rice-rice system

\begin{tabular}{|c|c|c|c|c|c|c|c|c|c|c|}
\hline Treatments & \multicolumn{5}{|c|}{$\mathrm{P}$ applied in kharif } & \multicolumn{5}{|c|}{$\mathrm{P}$ applied in kharif } \\
\hline & $100 \%$ & $75 \%$ & $50 \%$ & $25 \%$ & & $100 \%$ & $75 \%$ & $50 \%$ & $25 \%$ & \\
\hline & RDP & RDP & RDP & RDP & Mean & RDP & RDP & RDP & RDP & Mean \\
\hline Rabi & \multicolumn{5}{|c|}{ P Content $(\%)$} & \multicolumn{5}{|c|}{ Zinc content $\left(\mathrm{mg} \mathrm{kg}^{-1}\right)$} \\
\hline $100 \%$ RDP & 0.37 & 0.36 & 0.35 & 0.34 & 0.35 & 25.40 & 24.95 & 25.64 & 22.87 & 24.71 \\
\hline $75 \% \mathrm{RDP}$ & 0.35 & 0.35 & 0.34 & 0.33 & 0.34 & 23.53 & 22.97 & 21.8 & 22.47 & 22.69 \\
\hline $50 \% \mathrm{RDP}$ & 0.34 & 0.34 & 0.33 & 0.32 & 0.34 & 20.65 & 19.62 & 18.42 & 20.37 & 19.76 \\
\hline \multirow[t]{3}{*}{ Mean } & 0.36 & 0.35 & 0.34 & 0.33 & & 23.19 & 22.51 & 21.95 & 21.90 & \\
\hline & & & & & & \multirow{2}{*}{\multicolumn{5}{|c|}{$\begin{array}{c}K T x \\
R T\end{array}$}} \\
\hline & $K T$ & $R T$ & $K T \times R T$ & & & & & & & \\
\hline $\operatorname{SEm}( \pm)$ & 0.014 & 0.013 & 0.026 & & & 0.77 & 0.67 & 1.35 & & \\
\hline \multirow[t]{2}{*}{$\operatorname{LSD}(p<0.05)$} & $N S$ & $N S$ & $N S$ & & & $N S$ & 1.97 & 3.94 & & \\
\hline & \multicolumn{5}{|c|}{ P uptake $\left(\mathrm{kg} \mathrm{ha}^{-1}\right)$} & \multicolumn{5}{|c|}{ Zinc uptake $\left(\mathrm{g} \mathrm{ha}^{-1}\right)$} \\
\hline $100 \%$ RDP & 21.83 & 21.31 & 20.08 & 18.37 & 20.38 & 150 & 147 & 147 & 125 & 142 \\
\hline $75 \%$ RDP & 20.90 & 20.71 & 18.70 & 17.01 & 19.33 & 140 & 137 & 122 & 117 & 129 \\
\hline $50 \% \mathrm{RDP}$ & 19.68 & 18.98 & 17.42 & 15.32 & 17.85 & 119 & 110 & 96 & 96 & 107 \\
\hline \multirow[t]{3}{*}{ Mean } & 20.80 & 20.33 & 18.71 & 16.90 & & 136 & 131 & 125 & 113 & \\
\hline & & & & & & \multicolumn{5}{|c|}{ KTx } \\
\hline & $K T$ & $R T$ & $K T \times R T$ & & & $K T$ & $R T$ & $R T$ & & \\
\hline $\operatorname{SEm}( \pm)$ & 0.47 & 0.43 & 0.88 & & & 3.94 & 3.51 & 7.02 & & \\
\hline $\operatorname{LSD}(p<0.05)$ & 1.43 & 1.23 & 2.46 & & & 11.51 & 9.90 & 19.81 & & \\
\hline
\end{tabular}


Effect of $P$ on nutrient content and uptake of $P$ in rabi rice straw

There was no significant effect of applied $\mathrm{P}$ doses on P content of rice straw during rabi (Table 4) but significantly affected P uptake by its straw in the range of 7.13 to $7.97 \mathrm{~kg}$ ha $^{-1}$. Phosphorus @ 75 and 100\% RDP and 75 and 50\% RDP gave at par $\mathrm{P}$ uptake by rice straw as given in table 5 . The $\mathrm{P}$ uptake by rice straw during rabi increased with each increment of P applied earlier. However, P uptake by rice straw in rabi was on par in the plots during rabi when crop received 75 and $100 \%$ RDP in kharif. The interaction effect of rabi $\mathrm{P}$ doses and residual kharif treatments on $\mathrm{P}$ uptake by rabi rice straw was significant.

Table 4. Effect of fertilizer $\mathrm{P}$ on content and uptake of $\mathrm{P}$ and zinc in rabi rice straw under rice-rice system

\begin{tabular}{|c|c|c|c|c|c|c|c|c|c|c|}
\hline Treatments & \multicolumn{5}{|c|}{$\mathrm{P}$ applied in kharif } & \multicolumn{5}{|c|}{$\mathrm{P}$ applied in kharif } \\
\hline & $100 \%$ & $75 \%$ & $50 \%$ & $25 \%$ & & $100 \%$ & $75 \%$ & $50 \%$ & $25 \%$ & \\
\hline & RDP & RDP & RDP & RDP & Mean & RDP & RDP & RDP & RDP & Mean \\
\hline Rabi & \multicolumn{5}{|c|}{ P Content (\%) } & \multicolumn{5}{|c|}{ Zinc content $\left(\mathrm{mg} \mathrm{kg}^{-1}\right)$} \\
\hline $100 \%$ RDP & 0.133 & 0.134 & 0.130 & 0.125 & 0.130 & 29.59 & 29.36 & 28.64 & 28.82 & 29.10 \\
\hline $75 \%$ RDP & 0.143 & 0.127 & 0.125 & 0.119 & 0.128 & 29.10 & 28.48 & 27.50 & 26.75 & 27.96 \\
\hline $50 \% \mathrm{RDP}$ & 0.138 & 0.125 & 0.123 & 0.116 & 0.126 & 27.84 & 27.43 & 26.91 & 24.69 & 26.72 \\
\hline \multirow[t]{3}{*}{ Mean } & 0.138 & 0.128 & 0.126 & 0.12 & 0.128 & 28.84 & 28.42 & 27.69 & 26.75 & \\
\hline & \multicolumn{5}{|c|}{$K T x$} & \multicolumn{5}{|c|}{ KTx } \\
\hline & $K T$ & $R T$ & $R T$ & & & $K T$ & $R T$ & $R T$ & & \\
\hline SEm ( $( \pm)$ & 0.002 & 0.002 & $N S$ & & & 0.71 & 0.61 & 1.22 & & \\
\hline \multicolumn{11}{|l|}{$L S D(p<$} \\
\hline & 0.001 & 0.001 & $N S$ & & & $N S$ & 1.78 & 3.56 & & \\
\hline & \multicolumn{5}{|c|}{ P uptake $\left(\mathrm{kg} \mathrm{ha}^{-1}\right)$} & \multicolumn{5}{|c|}{ Zinc uptake $\left(\mathrm{g} \mathrm{ha}^{-1}\right)$} \\
\hline $100 \%$ RDP & 8.64 & 8.53 & 7.78 & 6.94 & 7.97 & 197 & 182 & 173 & 168 & 180 \\
\hline $75 \%$ RDP & 8.94 & 8.11 & 7.14 & 6.48 & 7.66 & 183 & 176 & 156 & 146 & 165 \\
\hline $50 \% \mathrm{RDP}$ & 9.14 & 6.88 & 6.68 & 5.88 & 7.13 & 184 & 151 & 146 & 129 & 153 \\
\hline \multirow[t]{3}{*}{ Mean } & 8.90 & 7.84 & 7.20 & 6.43 & & 188 & 170 & 158 & 147 & \\
\hline & \multicolumn{5}{|c|}{ KTx } & \multicolumn{5}{|c|}{ KTx } \\
\hline & $K T$ & $R T$ & $R T$ & & & $K T$ & $R T$ & $R T$ & & \\
\hline SEm ( \pm ) & 0.28 & 0.26 & 0.52 & & & 4.99 & 4.12 & 8.3 & & \\
\hline $\begin{array}{l}L S D(p< \\
0.05)\end{array}$ & 0.80 & 0.69 & 1.38 & & & 14.5 & 12.9 & 25.8 & & \\
\hline
\end{tabular}

Table 5. Effect of fertilizer $P$ on content and uptake of $P$ and zinc in kharif rice grain under rice-sunflower system

\begin{tabular}{lcccccc}
\hline Treatments & 2009 & 2010 & Mean & 2009 & 2010 & Mean \\
\hline P content (\%) & & & & Zinc content $\left(\mathrm{mg} \mathrm{kg}^{-1}\right)$ & & \\
\hline $100 \%$ RDP & 0.35 & 0.35 & 0.35 & 24.69 & 25.16 & 24.93 \\
$75 \%$ RDP & 0.34 & 0.34 & 0.34 & 24.65 & 24.86 & 24.76 \\
$50 \%$ RDP & 0.33 & 0.33 & 0.33 & 22.58 & 22.91 & 22.75 \\
$25 \%$ RDP & 0.33 & 0.33 & 0.33 & 20.42 & 20.55 & 20.49 \\
Mean & 0.34 & 0.34 & & 23.09 & 23.37 & \\
\hline & $Y$ & $T$ & $Y x T$ & $Y$ & $T$ & $Y x T$ \\
\hline SEm $( \pm)$ & 0.01 & 0.011 & 0.022 & 0.37 & 0.53 & 0.75 \\
LSD $(p<0.05)$ & $N S$ & $N S$ & $N S$ & $N S$ & 1.55 & $N S$ \\
\hline Puptake $\left.(\mathrm{kg} \mathrm{ha})^{-1}\right)$ & & & & Zinc uptake $\left(\mathrm{g} \mathrm{ha}^{-1}\right)$ & & \\
\hline $100 \%$ RDP & 19.80 & 19.93 & 19.86 & 140 & 144 & 142 \\
$75 \%$ RDP & 19.83 & 19.87 & 19.85 & 143 & 144 & 144 \\
$50 \%$ RDP & 17.85 & 18.03 & 17.94 & 122 & 124 & 123 \\
$25 \%$ RDP & 17.24 & 17.34 & 17.29 & 107 & 116 & 111 \\
Mean & 18.68 & 18.79 & & 128 & 132 & \\
\hline & $Y$ & $T$ & $Y x T$ & $Y$ & $T$ & $Y x T$ \\
\hline SEm $( \pm)$ & 0.40 & 0.56 & 0.78 & 2.48 & 3.50 & 4.95 \\
LSD $(p<0.05)$ & $N S$ & 1.62 & $N S$ & $N S$ & 10.02 & $N S$ \\
\hline
\end{tabular}


Effect of $P$ levels on content and uptake of zinc in rabi rice straw

The zinc content in rabi rice straw remained at par due to 100 and $75 \%$ RDP in rabi. Different rates of $P$ applied in preceding kharif did not affect zinc content of rabi rice straw. However, there was a gradual decrease in zinc content of rabi rice straw from 28.84 to $26.75 \mathrm{mg} \mathrm{kg}^{-1}$ (P applied in earlier kharif) decreased from 100 to $25 \%$ RDP. In general, high rates of $\mathrm{P}$ applied in rabi as well as kharif gave higher zinc content in rabi rice straw. The zinc uptake by rabi rice straw increased significantly with increased rates from 50 to 75 and 75 to $100 \%$ RDP (Table 6). It was significantly influenced by rates of $\mathrm{P}$ applied in kharif. Highest zinc uptake of $188 \mathrm{~g} \mathrm{ha}^{-1}$ was recorded in rabi rice straw when 100\% RDP was applied in kharif rice and was on par with 75\% RDP applied in preceding kharif. The uptake was on par in the plots that received 25 and 50\% RDP in kharif.

Table 6. Effect of fertilizer $\mathrm{P}$ on content and uptake of $\mathrm{P}$ and zinc in kharif rice straw under rice-sunflower system

\begin{tabular}{|c|c|c|c|c|c|c|}
\hline Treatments & 2009 & 2010 & Mean & 2009 & 2010 & Mean \\
\hline$P$ content $(\%)$ & & \multicolumn{5}{|c|}{ Zinc content ( $\left.\mathrm{mg} \mathrm{kg}^{-1}\right)$} \\
\hline $100 \%$ RDP & 0.15 & 0.15 & 0.15 & 29.45 & 29.39 & 29.42 \\
\hline $75 \% \mathrm{RDP}$ & 0.14 & 0.14 & 0.14 & 28.72 & 28.92 & 28.82 \\
\hline $50 \% \mathrm{RDP}$ & 0.14 & 0.14 & 0.14 & 27.82 & 27.58 & 27.70 \\
\hline $25 \%$ RDP & 0.13 & 0.13 & 0.13 & 26.01 & 26.29 & 26.15 \\
\hline \multirow[t]{2}{*}{ Mean } & 0.14 & 0.12 & & 28.00 & 28.04 & \\
\hline & $Y$ & $T$ & $Y \times T$ & $Y$ & $T$ & $Y \times T$ \\
\hline $\operatorname{SEm}( \pm)$ & 0.010 & 0.015 & 0.020 & 0.42 & 0.60 & 0.84 \\
\hline $\operatorname{LSD}(p<0.05)$ & $N S$ & $N S$ & $N S$ & $N S$ & 1.73 & $N S$ \\
\hline Puptake $\left(\mathrm{kg} \mathrm{ha}^{-1}\right)$ & & \multicolumn{5}{|c|}{ Zinc uptake $\left(\mathrm{g} \mathrm{ha}^{-1}\right)$} \\
\hline $100 \%$ RDP & 8.75 & 8.80 & 8.78 & 172 & 173 & 172 \\
\hline $75 \%$ RDP & 7.96 & 8.49 & 7.92 & 163 & 162 & 163 \\
\hline $50 \% \mathrm{RDP}$ & 7.84 & 7.64 & 7.74 & 156 & 153 & 155 \\
\hline $25 \%$ RDP & 6.91 & 6.89 & 6.90 & 137 & 139 & 138 \\
\hline Mean & 7.86 & 7.80 & & 157 & 158 & \\
\hline & $Y$ & $T$ & $Y \times T$ & $Y$ & $T$ & $Y \times T$ \\
\hline $\operatorname{SEm}( \pm)$ & 0.26 & 0.37 & 0.52 & 3.37 & 4.76 & 6.72 \\
\hline $\operatorname{LSD}(p<0.05)$ & $N S$ & 1.07 & $N S$ & $N S$ & 13.9 & $N S$ \\
\hline
\end{tabular}

${ }^{32}$ P based $P$-use efficiency parameters of rabirice

The effect of kharif residual $\mathrm{P}$ and rabi applied $\mathrm{P}$

levels on Pdff by rice dry matter at maximum tillering stage in rabi was significant. Increased rates of $\mathrm{P}$ applied in rabi significantly increased Pdff by rice dry matter. The difference in Pdff between any two levels of RDP was significant. However, the Pdff under these treatments remained in narrow range of 22.25 to $23.10 \%$. Highest Pdff of $26.72 \%$ was recorded due to combination of $100 \%$ RDP of rabi $\mathrm{P}$ in the plot that received $100 \% \mathrm{RDP}$ in kharif.

The $\mathrm{P}$ utilization by rabi rice at maximum tillering stage decreased with increased rate of rabi $\mathrm{P}$. The decrease with increased rate of $\mathrm{P}$ was significant for each consecutive level. It ranged from 25.31 to $29.34 \%$ due to kharif dose of 25 to $100 \%$ RDP. The P utilization of rabi dry matter remained on par with kharif applied 100 and 75, 75 and 50 and 50 and $25 \%$ RDP. The interaction effect of P levels applied fresh and kharif residual levels on $\mathrm{P}$ utilization by rabi rice dry matter was significant. The combination of $50 \%$ RDP of rabi dose in conjunction with any level of $\mathrm{P}$ applied in kharif gave significantly higher $\mathrm{P}$ utilization by rabi rice dry matter compared to corresponding combination of 75 and $100 \%$ RDP with kharif applied P levels.

The fertilizer P uptake of rabi rice dry matter was significantly influenced due to various levels of RDP applied to previous kharif crop and ranged from 3.60 to $5.31 \mathrm{~kg} \mathrm{ha}^{-1}$. Interaction effect of freshly applied rabi $\mathrm{P}$ with kharif residual $\mathrm{P}$ levels on fertilizer $\mathrm{P}$ uptake by rabi rice dry matter was significant. Maximum fertilizer P uptake was attained at higher levels of $\mathrm{P}$ applied (100 and 75\% RDP) both in rabi and preceding kharif. 
The soil-P uptake by rabi rice dry matter was significantly higher $\left(15.35 \mathrm{~kg} \mathrm{ha}^{-1}\right)$ with $100 \% \mathrm{RDP}$ in rabi and was significant compared to other levels of $\mathrm{P}$. It remained at par due to 50 and $75 \%$ RDP in rabi. The kharif $\mathrm{P}$ levels significantly affected soil $\mathrm{P}$ uptake by rice dry matter in rabi. It decreased gradually from 15.45 to $13.69 \mathrm{~kg} \mathrm{ha}^{-1}$ with decrease in rate of $\mathrm{P}$ in kharif from 100 to $25 \% \mathrm{RDP}$. The difference in soil $\mathrm{P}$ uptake between any consecutive $\mathrm{P}$ rates was non-significant but the difference between 100 and 25\% RDP was significant.

\section{Rice-sunflower system}

Effect of P on nutrient content and uptake of P in kharif rice

The $\mathrm{P}$ content of rice grain during kharif was at par across treatments and years (Table 5). The P uptake by rice grain during kharifindicated that it was significantly affected by $\mathrm{P}$ applied to the crop at different rates. The P uptake of grain due to $75 \%$ RDP was $19.85 \mathrm{~kg} \mathrm{ha}^{-1}$ and was at par with $100 \%$ RDP and significantly superior to $50 \%$ RDP $(17.94 \mathrm{~kg}$ $\left.\mathrm{ha}^{-1}\right)$.

\section{Effect of $P$ on content and uptake of zinc in rice grain}

The zinc content of rice grain during kharif was significantly influenced by levels of $\mathrm{P}$ applied to the crop (Table 5) $\mathrm{mgkg}^{-1}$. Application of 75 and 100\% RDP recorded similar zinc content of 24.76 and $24.93 \mathrm{mgkg}^{-1}$ respectively. However lower doses of $\mathrm{P}$ applied beyond $75 \%$ RDP resulted in significantly lower zinc content in rice grain. Application of lower doses of P@25 and 50\% RDP gave significantly lower zinc uptake by rice grain compared to 75 and $100 \%$ RDP.

\section{Effect of $P$ on nutrient content and uptake of $P$ in rice straw}

The $\mathrm{P}$ content in rice straw during kharif was not influenced by the levels of $\mathrm{P}$ application. It is also observed that there was no significant difference in $\mathrm{P}$ content of rice straw due to effect of years and treatment or years(Table 6). The P uptake by kharif straw as affected by different levels of $\mathrm{P}$ application indicated that it was highest due to $100 \% \mathrm{RDP}$ dose. However, uptake was on par with that of $75 \%$ RDP.

\section{Effect of $P$ on content and uptake of zinc in rice straw}

The zinc content in kharif rice straw decreased significantly with reduced levels of $\mathrm{P}$ application (Table 6). The zinc content of rice straw was significantly higher due to
$100 \%$ RDP over $25 \%$ RDP. The zinc content of kharif rice straw was not influenced by interaction of years and treatments. The zinc uptake by kharif rice straw indicated that it was minimum (138 $\mathrm{kg} \mathrm{ha}^{-1)}$ when P was applied @ 25\% RDP. Highest zinc uptake by straw was obtained due to application of $100 \%$ RDP and it was on par with that of $75 \%$ RDP.

\section{${ }^{32}$ P based P-use efficiency parameters of kharif rice crop}

The Pdff by kharif rice dry matter at maximum tillering stage was significantly affected by $\mathrm{P}$ applied to the crop. The Pdff in rice dry matter ranged from 16.23 to $26.17 \%$. The effect of years of on Pdff by kharif rice was not significant. However, interaction of years and treatments on Pdff by rice dry matter was significant. The $\mathrm{P}$ utilization by rice dry matter at maximum tillering stage increased significantly from $22.36 \%(100 \% \mathrm{RDP})$ with each decrement of P to $38.04 \%$ by P applied @ $25 \%$ RDP.

The fertilizer $P$ uptake by rice dry matter was lowest $\left(3.04 \mathrm{~kg} \mathrm{ha}^{-1}\right)$ due to $25 \% \mathrm{RDP}$ and highest $\left(5.55 \mathrm{~kg} \mathrm{ha}^{-1}\right)$ due to $100 \%$ RDP. The fertilizer P uptake by rice dry matter at maximum tillering stage was not affected by years or interaction of years and treatments. The soil-P uptake by rice dry matter at maximum tillering stage during kharif indicated that it was highest when crop was supplied with $100 \%$ RDP (16.36 $\left.\mathrm{kg} \mathrm{ha}^{-1}\right)$ and was on par with 75 and 50\% RDP. However, soil P uptake recorded due to 75 or $50 \%$ RDP was significantly higher than that of $25 \% \operatorname{RDP}\left(13.80 \mathrm{~kg} \mathrm{ha}^{-1}\right)$.

\section{Effect of $P$ on nutrient content and uptake of $P$ in sunflower} seed

Phosphorus content in rabi sunflower seed decreased from 0.39 to $0.37 \%$ with reduced $P$ application to rabi sunflower from 100 to 50\% RDP (Table 7). The P uptake decreased in rabi sunflower seed as P application to rabi crop decreased from 100 to $75 \%$ RDP but P uptake at 100\% RDP was significantly higher over 50\% RDP. However, P uptake by rabi sunflower that received 75 and 100\% RDP in earlier kharif was significantly higher over 25 and 50\% RDP applied in kharif. The cumulative effect of kharif and rabi applied $\mathrm{P}$ significantly affected $\mathrm{P}$ uptake by rabi sunflower seed. The combination of 100 and $75 \%$ RDP applied in rabi with 100 or $75 \%$ RDP in kharif were at par and higher compared to lower doses. 
Table 7. Effect of fertilizer $\mathrm{P}$ on content and uptake of $\mathrm{P}$ and zinc in sunflower seed under rice--sunflower system

\begin{tabular}{|c|c|c|c|c|c|c|c|c|c|c|}
\hline \multirow[t]{3}{*}{ Treatments } & \multicolumn{5}{|c|}{$\mathrm{P}$ applied in kharif } & \multicolumn{5}{|c|}{$\mathrm{P}$ applied in kharif } \\
\hline & $100 \%$ & $75 \%$ & $50 \%$ & $25 \%$ & & $100 \%$ & $75 \%$ & $50 \%$ & $25 \%$ & \\
\hline & RDP & RDP & RDP & RDP & Mean & RDP & RDP & $\mathrm{RDP}$ & RDP & Mean \\
\hline Rabi & \multicolumn{5}{|c|}{$\mathrm{P}$ content $(\%)$} & \multicolumn{5}{|c|}{ Zinc content $\left(\mathrm{mg} \mathrm{kg}^{-1}\right)$} \\
\hline $100 \%$ RDP & 0.41 & 0.39 & 0.39 & 0.36 & 0.39 & 31.22 & 30.57 & 29.17 & 28.69 & 29.91 \\
\hline $75 \%$ RDP & 0.40 & 0.40 & 0.39 & 0.35 & 0.39 & 29.87 & 28.59 & 28.41 & 27.51 & 28.60 \\
\hline $50 \%$ RDP & 0.39 & 0.38 & 0.37 & 0.34 & 0.37 & 28.45 & 27.56 & 27.12 & 26.43 & 27.39 \\
\hline \multirow[t]{3}{*}{ Mean } & 0.40 & 0.39 & 0.38 & 0.35 & 0.38 & 29.85 & 28.91 & 28.23 & 27.54 & \\
\hline & \multirow{2}{*}{\multicolumn{5}{|c|}{$\begin{array}{c}K T x \\
R T\end{array}$}} & \multirow{2}{*}{\multicolumn{5}{|c|}{$\begin{array}{c}K T x \\
R T\end{array}$}} \\
\hline & & & & & & & & & & \\
\hline $\operatorname{SEm}( \pm)$ & 0.01 & 0.01 & 0.02 & & & 0.80 & 0.70 & 1.39 & & \\
\hline \multirow[t]{2}{*}{$L S D(p<0.05)$} & $N S$ & $N S$ & $N S$ & & & 2.35 & 2.03 & 4.05 & & \\
\hline & \multicolumn{5}{|c|}{ P uptake $\left(\mathrm{kg} \mathrm{ha}^{-1}\right)$} & \multicolumn{5}{|c|}{ Zinc uptake $\left(\mathrm{g} \mathrm{ha}^{-1}\right)$} \\
\hline $100 \% \mathrm{RDP}$ & 7.22 & 6.77 & 5.85 & 5.28 & 6.26 & 55.01 & 53.04 & 43.78 & 42.06 & 48.34 \\
\hline $75 \%$ RDP & 7.15 & 6.56 & 5.60 & 4.90 & 6.03 & 53.38 & 46.92 & 40.77 & 38.51 & 44.77 \\
\hline $50 \%$ RDP & 6.40 & 5.90 & 5.11 & 4.44 & 5.44 & 46.66 & 42.80 & 37.48 & 34.49 & 40.26 \\
\hline \multirow[t]{3}{*}{ Mean } & 6.92 & 6.41 & 5.52 & 4.87 & & 51.62 & 47.49 & 40.64 & 38.29 & \\
\hline & \multicolumn{5}{|c|}{$K T x$} & \multicolumn{5}{|c|}{ KTx } \\
\hline & $K T$ & $R T$ & $R T$ & & & $K T$ & $R T$ & $R T$ & & \\
\hline SEm ( \pm ) & 0.24 & 0.21 & 0.42 & & & 1.27 & 1.08 & 2.15 & & \\
\hline$L S D(p<0.05)$ & 0.69 & 0.61 & 1.23 & & & 3.70 & 3.19 & 6.38 & & \\
\hline
\end{tabular}

Effect of P on content and uptake of zinc in sunflower seed

The zinc content decreased significantly from $29.91 \mathrm{mg} \mathrm{kg}^{-1}$ due to $100 \% \mathrm{RDP}$ applied in rabi to $27.39 \mathrm{mg}$ $\mathrm{kg}^{-1}$ by $50 \%$ (Table 7). The effect of $\mathrm{P}$ applied in kharif significantly affected the zinc content of rabi sunflower seed. It decreased gradually with decreased P made in kharif. The difference between zinc content of rabi sunflower seed was highly significant when compared between residual effects of 100 and $25 \%$ RDP in kharif.

The zinc uptake by rabi sunflower seed was significantly influenced by application of P in rabi (Table 7). The zinc uptake of rabi sunflower seed in high $\mathrm{P}$ soil significantly decreased as $\mathrm{P}$ application made in kharif rice decreased at a regular interval. The interaction of direct rabi and kharif residual $\mathrm{P}$ indicated that $100 \%$ RDP of rabi in conjunction with 100 or $75 \%$ RDP in kharif resulted in similar zinc uptake in rabi sunflower seed.

Effect of $P$ on nutrient content and uptake of $P$ in sunflower stalk

There was non-significant decrease in $\mathrm{P}$ content in rabi sunflower stalk (Table 8) due to phosphorus applied in kharif crop (25 to $100 \%$ RDP).. The P uptake by rabi sunflower stalk significantly decreased as $\mathrm{P}$ application to rabi crop decreased from 100 to $50 \%$ RDP. These differences in reduction of $\mathrm{P}$ uptake were significant between any two successive levels of $\mathrm{P}$. Phosphorus uptake by rabi sunflower stalk was significantly lower with each decrement rate of $\mathrm{P}$ applied to kharif rice. The P uptake decreased from 2.73 (100\% RDP) to $1.54 \mathrm{~kg} \mathrm{ha}^{-1}(25 \% \mathrm{RDP})$ applied in kharif. The interaction of rates of $\mathrm{P}$ applied in rabi and earlier kharif was significant on P uptake by rabi sunflower stalk. 
Table 8. Effect of fertilizer $\mathrm{P}$ on content and uptake of $\mathrm{P}$ and zinc in sunflower stalk under rice-sunflower system

\begin{tabular}{|c|c|c|c|c|c|c|c|c|c|c|}
\hline \multirow[t]{2}{*}{ Treatments } & \multicolumn{5}{|c|}{$\mathrm{P}$ applied in kharif } & \multicolumn{5}{|c|}{$\mathrm{P}$ applied in kharif } \\
\hline & $100 \%$ & $75 \%$ & $50 \%$ & $25 \%$ & & $100 \%$ & $75 \%$ & $50 \%$ & $25 \%$ & \\
\hline & RDP & RDP & RDP & RDP & Mean & RDP & RDP & RDP & RDP & Mean \\
\hline Rabi & \multicolumn{5}{|c|}{$\mathrm{P}$ content $(\%)$} & \multicolumn{5}{|c|}{ Zinc content $\left(\mathrm{mg} \mathrm{kg}^{-1}\right)$} \\
\hline $100 \%$ RDP & 0.12 & 0.10 & 0.09 & 0.08 & 0.10 & 19.65 & 18.74 & 17.60 & 16.94 & 18.23 \\
\hline $75 \%$ RDP & 0.10 & 0.09 & 0.08 & 0.07 & 0.09 & 18.31 & 17.98 & 17.17 & 16.27 & 17.43 \\
\hline $50 \% \mathrm{RDP}$ & 0.09 & 0.08 & 0.07 & 0.07 & 0.08 & 17.69 & 17.27 & 16.58 & 15.58 & 16.78 \\
\hline \multirow[t]{3}{*}{ Mean } & 0.10 & 0.09 & 0.08 & 0.07 & & 18.55 & 18.00 & 17.12 & 16.26 & \\
\hline & \multicolumn{5}{|c|}{$K T x$} & \multicolumn{5}{|c|}{$K T x$} \\
\hline & KT & $R T$ & $R T$ & & & $K T$ & $R T$ & $R T$ & & \\
\hline $\operatorname{SEm}( \pm)$ & 0.019 & 0.017 & 0.035 & & & 0.47 & 0.41 & 0.82 & & \\
\hline \multirow[t]{2}{*}{$L S D(p<0.05)$} & $N S$ & $N S$ & $N S$ & & & 1.37 & 1.19 & 2.39 & & \\
\hline & \multicolumn{5}{|c|}{ P uptake $\left(\mathrm{kg} \mathrm{ha}^{-1}\right)$} & \multicolumn{5}{|c|}{ Zinc uptake $\left(\mathrm{g} \mathrm{ha}^{-1}\right)$} \\
\hline $100 \%$ RDP & 3.30 & 2.57 & 2.03 & 1.71 & 2.37 & 54.01 & 48.14 & 39.76 & 36.20 & 44.28 \\
\hline $75 \%$ RDP & 2.76 & 2.33 & 1.77 & 1.44 & 2.05 & 50.52 & 46.64 & 37.93 & 33.58 & 41.95 \\
\hline $50 \%$ RDP & 2.17 & 1.93 & 1.44 & 1.48 & 1.74 & 42.67 & 41.62 & 34.09 & 32.86 & 37.70 \\
\hline \multirow[t]{3}{*}{ Mean } & 2.73 & 2.27 & 1.74 & 1.54 & & 48.97 & 45.43 & 37.22 & 34.21 & \\
\hline & \multicolumn{5}{|c|}{$K T x$} & \multicolumn{5}{|c|}{ KTx } \\
\hline & $K T$ & $R T$ & $R T$ & & & $K T$ & $R T$ & $R T$ & & \\
\hline $\operatorname{SEm}( \pm)$ & 0.11 & 0.09 & 0.18 & & & 1.49 & 1.32 & 2.63 & & \\
\hline$L S D(p<0.05)$ & 0.31 & 0.27 & 0.54 & & & 4.35 & 3.85 & 7.67 & & \\
\hline
\end{tabular}

Effect of P levels on content and uptake of zinc in sunflower stalk

The zinc content of rabi sunflower stalk decreased gradually and significantly as level of $\mathrm{P}$ applied in rabi decreased (Table 8). It was significantly lower at 50 and $25 \%$ RDP applied in kharif rice than $100 \%$ RDP. The interaction of rates of $\mathrm{P}$ applied in rabi and in preceding kharif rice significantly affected zinc content of rabi sunflower stalks. The cumulative effect of $100 \%$ RDP of kharif along with $100 \%$ RDP of rabi was at par with $100 \%$ RDP of $r a b i+75 \%$ RDP of kharif $\left(18.74 \mathrm{mg} \mathrm{kg}^{-1}\right)$.

The zinc uptake by rabi sunflower stalk was at par due to rabi P application at 100 and $75 \%$ RDP (Table 8 ). The zinc uptake was significantly lower $\left(37.7 \mathrm{~g} \mathrm{ha}^{-1}\right)$ in stalks when $50 \%$ RDP was applied. Decreasing rate of P application to kharif rice decreased zinc uptake by subsequent rabi sunflower stalks. The cumulative effect of $\mathrm{P}$ applied during both seasons significantly influenced the zinc uptake by rabi sunflower stalk.
${ }^{32}$ P based P-use efficiency parameters of rabi sunflower Pdff by sunflower dry matter at bud initiation stage

The Pdff decreased significantly when rabi $\mathrm{P}$ application was reduced from 100 to $75 \%$ RDP and it remained at par with 50\% RDP crop. The residual effect of kharif $\mathrm{P}$ significantly affected the Pdff by rabi sunflower dry matter. It decreased significantly when rate of $\mathrm{P}$ applied in kharif decreased from 100 to $75 \%$ RDP. The Pdff by sunflower dry matter was highest $(29.34 \%)$ due to cumulative effect of RDP @ 100\% during rabi and earlier kharifrice.

Per cent $P$ utilization by sunflower dry matter at bud initiation stage

The P utilization increased significantly from 6.67 to $9.46 \%$ with decrease in rate of rabi $\mathrm{P}$ application. The difference in $\mathrm{P}$ utilization by rabi sunflower dry matter between any two levels of $\mathrm{P}$ applied in rabi was significant. The $\mathrm{P}$ applied in kharif rice significantly reduced the $\mathrm{P}$ 
utilization by sunflower dry matter with each decrement in rates of kharif $\mathrm{P}$ application. The residual effect resulted in decreased P utilization by sunflower from 10.47 to $5.75 \%$. The interaction of kharif and rabi $\mathrm{P}$ levels on $\mathrm{P}$ utilization by sunflower dry matter was significant.

Fertilizer P uptake by sunflower dry matter at bud initiation stage

The fertilizer P uptake by rabi sunflower dry matter decreased significantly with each decrement in $\mathrm{P}$ application. The fertilizer P uptake decreased from 2.02 to $1.04 \mathrm{~kg} \mathrm{ha}^{-1}$ significantly with each level of reduced $\mathrm{P}$ application in rice. The interaction of rates of $\mathrm{P}$ applied in rabi and preceding kharif rice indicated that highest $P$ uptake of $2.35 \mathrm{~kg} \mathrm{ha}^{-1}$ could be attained with $100 \%$ RDP in both seasons.

Soil P uptake by sunflower dry matter at bud initiation stage The soil $\mathrm{P}$ uptake by sunflower dry matter recorded at 50\% RDP in rabi was significantly lower $\left(4.47 \mathrm{~kg} \mathrm{ha}^{-1}\right)$ over 75 or $100 \%$ RDP. It decreased significantly due to 50 or
$25 \%$ RDP in kharif than $100 \%$ RDP of kharif. The interaction effect of $100 \%$ RDP applied in both seasons, $100 \%$ RDP of kharif $+75 \%$ RDP of rabi and $100 \%$ RDP of $r a b i+75 \%$ RDP of kharif were significantly higher compared to lower rate combinations of kharif and rabi seasons.

Relationship between fertilizer $P$ and soil $P$ uptake in different systems

The relationship between fertilizer and soil P uptake in kharif and rabi rice under rice-rice and rice-sunflower systems are depicted in Fig 1. In kharif, there was a significantly higher predictability of 0.99 under rice-sunflower compared to 0.76 under rice-rice system. The rate of change in soil $\mathrm{P}$ uptake for an unit change in fertilizer $\mathrm{P}$ uptake was also higher in ricesunflower system $\left(0.96 \mathrm{~kg} \mathrm{ha}^{-1}\right)$ compared to rice-rice system $\left(0.65 \mathrm{~kg} \mathrm{ha}^{-1}\right)$. In rabi season, there was a significantly higher predictability of 0.90 under rice-sunflower compared to 0.67 under rice-rice system. The rate of change in soil P uptake for an unit change in fertilizer $\mathrm{P}$ uptake was also higher in ricesunflower system $\left(1.27 \mathrm{~kg} \mathrm{ha}^{-1}\right)$ compared to rice-rice system $\left(1.09 \mathrm{~kg} \mathrm{ha}^{-1}\right)$.

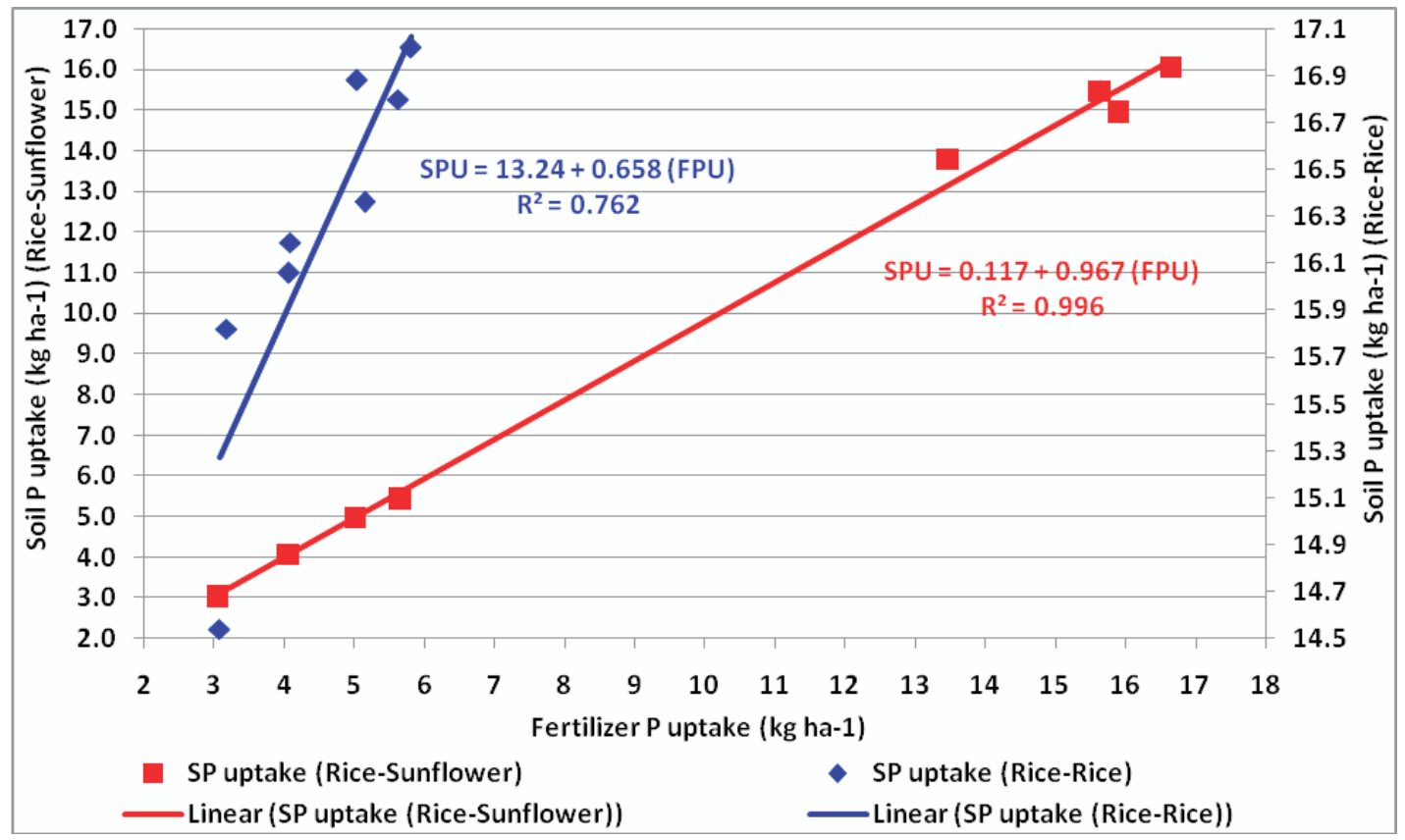




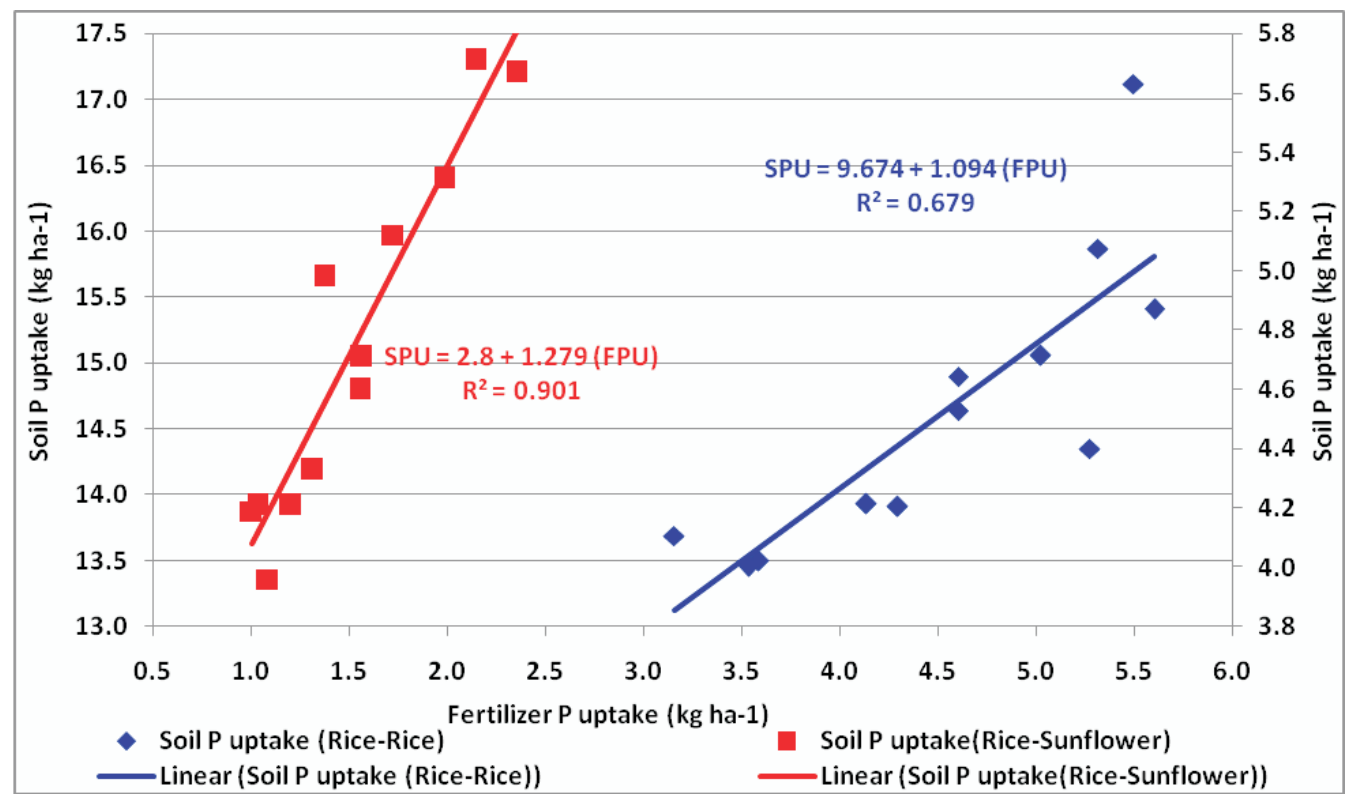

Fig. 1. Relationship between fertilizer and soil P uptake in kharif and rabi seasons under rice-rice and rice-sunflower systems

Relationship between $P$ utilization and Pdff in different systems

The relationship between $\mathrm{P}$ utilization and Pdff under rice-rice and rice-sunflower systems are depicted in Fig 2. There was a negative relationship between Pdff and P utilization in kharif and rabi under rice-rice and ricesunflower systems. In kharif, there was a significantly higher predictability of 0.905 under rice-rice compared to 0.855 under rice-sunflower system. The rate of change in $\mathrm{P}$ utilization for an unit change in Pdff was higher in rice-rice $(1.629 \%)$ compared to rice-sunflower system $\left(1.378 \mathrm{~kg} \mathrm{ha}^{-1}\right)$. In rabi, there was a significantly higher predictability of 0.845 under rice-rice compared to 0.219 under ricesunflower system. The rate of change in P utilization for an unit change in Pdff was also higher in rice-rice (-2.552\%) compared to rice-sunflower system $(0.331 \%)$.

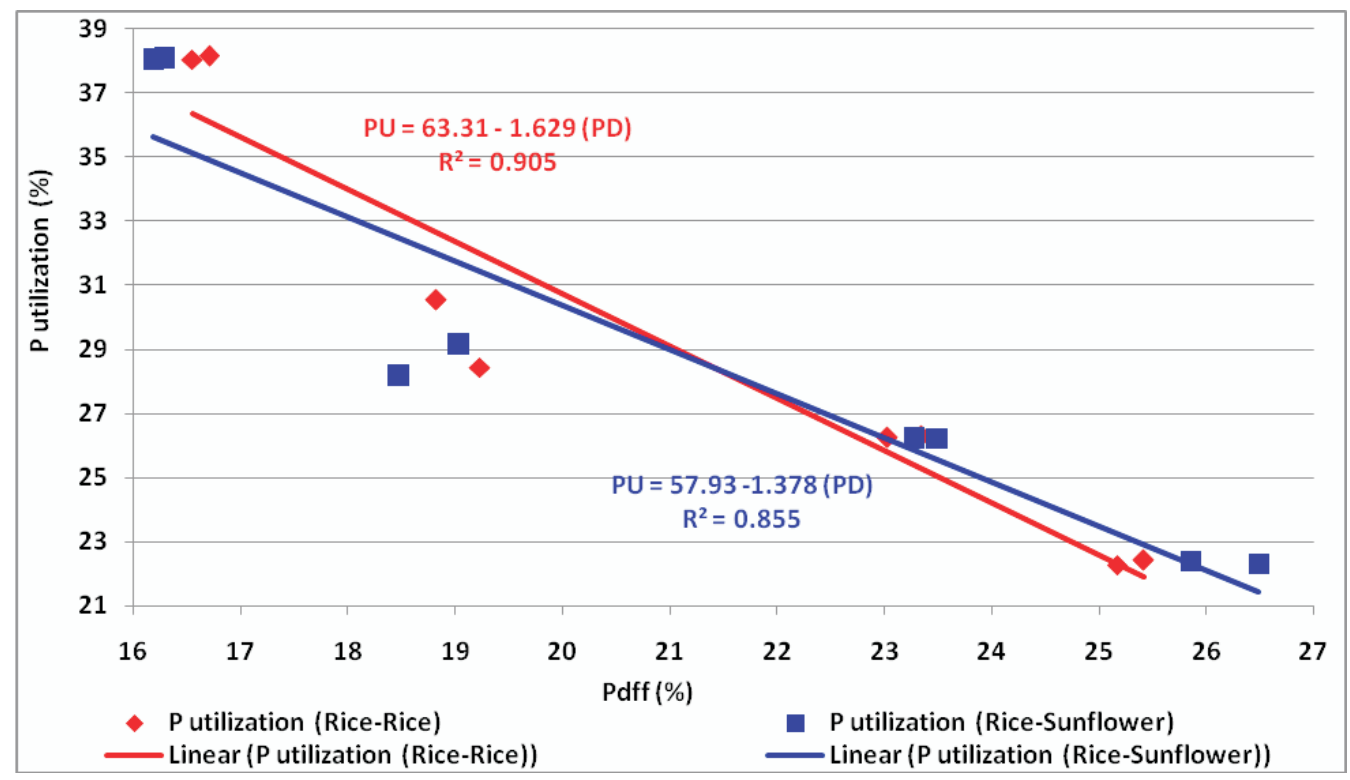




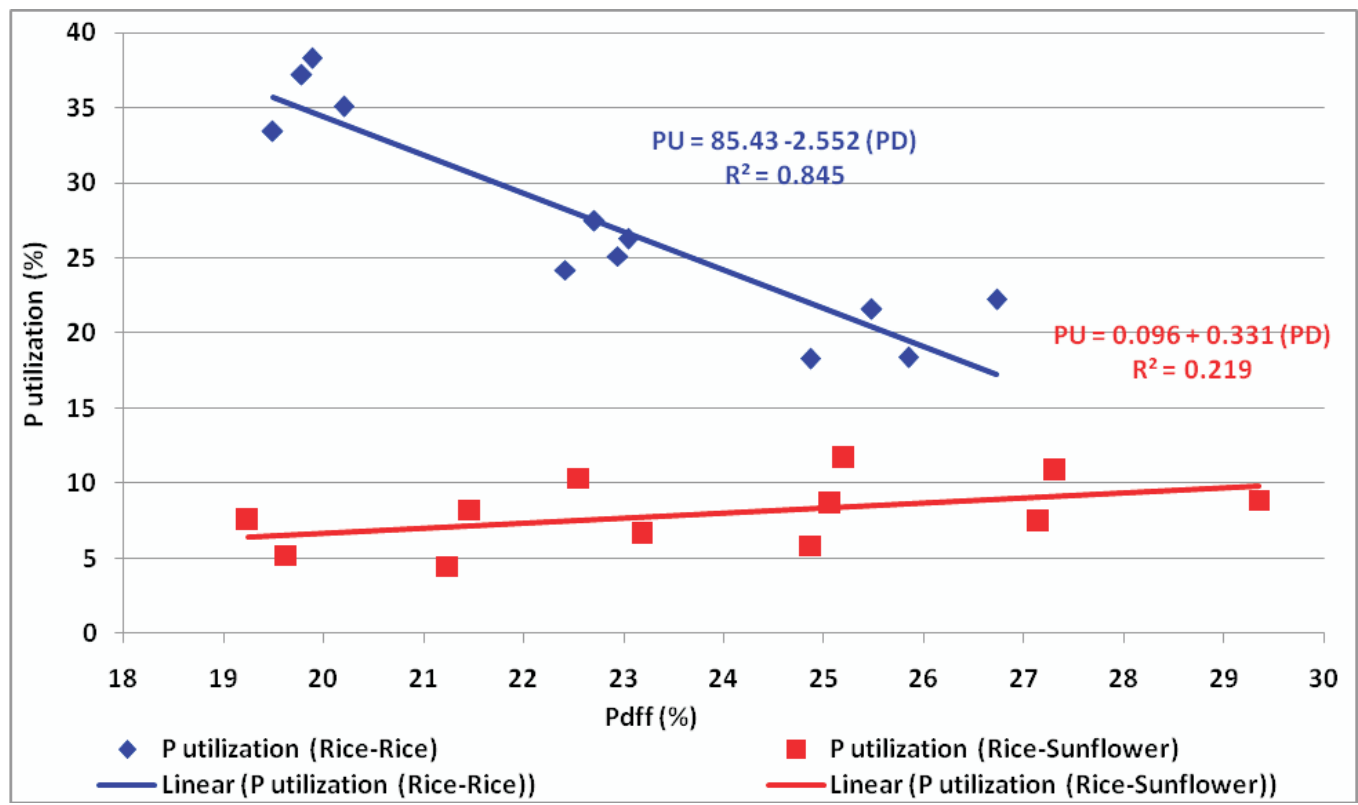

Fig. 2. Relationship between Pdff and $\mathrm{P}$ utilization in kharif and rabi seasons under rice-rice and rice-sunflower systems

Effect of $P$ application on rice under rice-rice and ricesunflower systems

Application of $\mathrm{P}$ during kharif to rice either in ricerice or rice-sunflower systems indicated that rice grain yield remained similar due to 100 and $75 \%$ RDP. In rice-rice system, the grain yield was at par in the range of 5668 to 5775 $\mathrm{kg} \mathrm{ha}^{-1}$ with application of P@ 75 to 100\% RDP. Similarly, rice grain yield remained at par due to treatments in pooled kharif rice of rice-sunflower system. Higher soil P of $126 \mathrm{~kg}$ $\mathrm{P}_{2} \mathrm{O}_{5} \mathrm{ha}^{-1}$ was beneficial to attain at par rice yield when recommended dose was reduced by $25 \%$. Reduction in RDP to $50 \%$ gave lower yields compared to 75 or $100 \%$ RDP. Hence there is a possibility of saving $25 \%$ dose in $\mathrm{P}$ recommendation to kharif rice. Surendra Babu et al. (2006) reported that in high $\mathrm{P}$ soils having available $\mathrm{P}_{2} \mathrm{O}_{5}$ range of 62 to 94 , it is possible to reduce $\mathrm{P}$ dose to rice by $25 \%$. The $\mathrm{P}$ content in kharif rice grain and straw of both systems was not affected due to different $\mathrm{P}$ levels. The $\mathrm{P}$ uptake by rice grain ranged from 17.4 to $19.97 \mathrm{~kg} \mathrm{ha}^{-1}$ due to different rates of $\mathrm{P}$ in rice under rice-rice system and from 17.29 to $19.86 \mathrm{~kg} \mathrm{ha}^{-1}$ in kharif rice under rice-sunflower system. The increased $\mathrm{P}$ uptake by rice grain at $100 \%$ RDP was because of higher yield realization.
In spite of initial soil DTPA Zn of $3.1 \mathrm{mg} \mathrm{kg}^{-1}$, the $\mathrm{Zn}$ content of rice grain decreased under both cropping systems with a reduction in the RDP levels. Such a decrement in $\mathrm{Zn}$ content of rice grain was noticed for rice under rice-sunflower system. Bogdavonic et al (1999) reported that high $\mathrm{P}$ level in soil would reduce availability of zinc to crops. However, increased rates of $\mathrm{P}$ from 25 to $100 \%$ slightly increased $\mathrm{Zn}$ content of grain and straw of kharif rice. This was due to the fact that soil had high $\mathrm{P}$ and sufficient available $\mathrm{Zn}$ and rate of applied $\mathrm{P}$ was below the recommended dose. Similar trend was observed in $\mathrm{Zn}$ content in kharif rice straw.

The Pdff of rice dry matter in kharif got reduced from 25.29 to $16.62 \%$ in rice-rice system and from 26.22 to $16.20 \%$ in rice-sunflower system as rate of $\mathrm{P}$ application was reduced from 100 to $25 \%$ RDP. Increased Pdff and fertilizer $\mathrm{P}$ uptake by crops with increased rate of $\mathrm{P}$ application was observed as reported for low to medium soils for other crops (Giri and Venkata Reddy 2005).

Thus, utilization of applied $\mathrm{P}$ by kharif rice increased significantly with reduced $\mathrm{P}$ application. The $\mathrm{P}$ utilization by kharif rice dry matter was $70 \%$ higher due to $25 \%$ RDP compared to $100 \%$ RDP. The soil P uptake reduced with decreased rate of $\mathrm{P}$ application and ranged 
from 13.8-16.91 $\mathrm{kg} \mathrm{ha}^{-1}$ across different treatments of rice dry matter under both systems.

Effect of rabi applied $P$ and kharif residual $P$ on rabi rice of rice-rice system

The rabi rice grain yield was significantly affected fertilizer application in rabi. However, P @ 100 and 75\% RDP of rabi gave at par yield of 5654 and $5760 \mathrm{~kg} \mathrm{ha}^{-1}$. Similar trend was observed in straw yield. Phosphors can be reduced by $25 \%$ in rabi rice of rice-rice system. The grain and straw yields decreased from 5876 to 5130 and 6319 to 5361 $\mathrm{kg} \mathrm{ha}^{-1}$ respectively as kharif $\mathrm{P}$ dose decreased from 100 to $25 \%$ RDP. The yields obtained in plots that received either 100 or $75 \%$ RDP in kharif resulted in at par yield in rabi. In a medium P soil, Rao et al (1989) tried different P levels in rice based system and reported that rice yield increased due to residual effect of P @ 80 and $120 \mathrm{~kg} \mathrm{ha}^{-1}$ in earlier crop. In present study, yields were maintained even after reducing $25 \%$ of RDP but decreased when reduction was beyond $25 \%$.

The cumulative effect also indicated that rabi grain and straw yield can be same even when $100 \%$ RDP was applied in rabi to plots that received 50\% RDP in kharif. However, across both seasons, there was a possibility of saving $\mathrm{P}$ by $25 \%$ in kharif $+25 \%$ in rabi although $100 \% \mathrm{P}$ in rabi applied to plots that received 50\% RDP in kharif was similar. The $\mathrm{P}$ uptake of rabi rice grain and straw decreased considerably due to reduced $\mathrm{P}$ application of either fresh $\mathrm{rabi}$ levels of P or residual levels of kharif applied P. Similar results were reported by Surendra Babu et al., (2005) for maize raised on a high $P$ soil.

The $\mathrm{Zn}$ content of rabi rice grain and straw decreased with decrease in $\mathrm{P}$ application in rabi or kharif to previous crop. It appeared that whenever recommended $\mathrm{P}$ was applied, $\mathrm{Zn}$ content of crop was at highest level. The lower levels of $\mathrm{Zn}$ content was above to normal content registered in crop produce. Gill et al (2004) observed that $\mathrm{P}$ induced reduction in shoot $\mathrm{Zn}$ concentration ranged between $22 \%$ in maize to $50 \%$ in sunflower. They revealed that differential $\mathrm{P}$ and $\mathrm{Zn}$ use efficiencies of maize and sunflower caused significant difference in P-Zn interactions.
The Pdff of rabi rice dry matter decreased as rate of Preduced in rabi and kharif. The reduction in Pdff due to rabi $P$ application was significant and reflected similar results like direct effect of P on Pdff of rice dry matter in kharif. Residual effect of kharif applied P was not affecting Pdff in rabi and it is expected that $\mathrm{P}$ was tagged freshly to rabi P only. Similarly, Pdff continued to be higher due to combination of freshly applied $100 \%$ rabi RDP in conjunction with any $\mathrm{P}$ rate applied to preceding kharif. The fertilizer $\mathrm{P}$ uptake of rabi rice dry matter was higher when crop received combined dose of 75 or $100 \%$ RDP in both seasons. The P utilized by rabi crop remained higher with lower rates of $\mathrm{P}$ of either rabi or kharif. It is clear from Pdff, fertilizer P uptake and $\mathrm{P}$ utilization of rabi rice that kharif applied $\mathrm{P}$ helped in rabi to realize higher $\mathrm{P}$ utilization by crop than what could be achieved in terms of Pdff and fertilizer P uptake. The soil P uptake by rabi rice dry matter was lower than that of kharif.

Effect of rabi applied $P$, kharif residual $P$ and cumulative influence on sunflower

Application of fresh P levels during rabi indicated that sunflower seed yield was at par irrespective of 100 or $75 \%$ RDP application indicating that there was a possibility of reducing P by $25 \%$ RDP of sunflower. However, reducing RDP beyond 25\% resulted in similar yield like that of $75 \%$ RDP but not $100 \%$ RDP. The stalk yield of sunflower also resulted in a similar trend. The cumulative study indicated that $25 \%$ RDP each in kharif rice and rabi sunflower could be adopted to attain similar yields of seed and stalk.

The zinc content gradually decreased in sunflower seed and stalk from 29.91 to $27.39,18.23$ to $16.78 \mathrm{mg} \mathrm{kg}^{-1}$ where $\mathrm{P}$ was applied to kharif crop. Similar trend was reflected in $\mathrm{Zn}$ uptake of both seed and stalk of sunflower. This observation made for crop and reasons ascribed for such phenomenon were discussed in rabi rice of rice-rice system.

${ }^{32} \mathrm{P}$ isotope was employed in sunflower of ricesunflower system. The applied rabi $\mathrm{P}$ decreased Pdff of sunflower dry matter at bud initiation stage from 25.8 to $22.1 \%$ as P levels were reduced. The residual effect of kharif treatments indicated that Pdff decreased from 27.3 to $20.3 \%$ 
as $\mathrm{P}$ applied in rice decreased from 100 to $25 \% \mathrm{RDP}$. This was in contrast to what was observed in rabi rice of rice-rice system where Pdff remained similar across kharif residual $\mathrm{P}$ treatments. The reason for such difference between Pdff of rice and sunflower in rabi under rice based system needs to be investigated.

The fertilizer P uptake by sunflower dry matter at bud initiation stage ranged from 1.27 to $1.78 \mathrm{~kg} \mathrm{ha}^{-1}$ as $\mathrm{P}$ application increased from 50 to $100 \%$ RDP. The fertilizer $\mathrm{P}$ uptake decreased with lower levels of $\mathrm{P}$ as in Pdff. Phosphorus application made in kharif also reduced (2.02 to $1.04 \mathrm{~kg} \mathrm{ha}^{-1}$ ) fertilizer P uptake in sunflower in proportion to decremental levels of kharif $\mathrm{P}$. The combined effect of kharif and rabi $\mathrm{P}$ application gave high fertilizer $\mathrm{P}$ uptake by sunflower dry matter due to 100 or $75 \%$ RDP applied during rabi on plots that received $100 \%$ RDP in kharif. The $\mathrm{P}$ utilization of applied P by sunflower dry-matter decreased with increment of $r a b i \mathrm{P}$ application as plots that received $\mathrm{P}$ in kharif got reduced from 100 to $25 \%$. The soil P uptake by sunflower dry matter during rabi was lower with reduced $P$ of rabi dose. The residual effect of kharif $\mathrm{P}$ also indicated reduced soil $\mathrm{P}$ uptake from 5.38 to $4.09 \mathrm{~kg} \mathrm{ha}^{-1}$ as kharif $\mathrm{P}$ dose decreased from 100 to $25 \%$ RDP. Decreased soil P uptake at lower level of kharif or rabi treatments was due to lower yield realization as implied in total P removal by crop. The study indicated that $25 \% \mathrm{P}$ fertilizer could be saved from current recommended dose in both crops. Phosphorus removal by rice and sunflower was at par for 100 and $75 \%$ RDP applied to both crops. Thus reducing $\mathrm{P}$ by $25 \%$ from current RDP of rice and sunflower in both cropping systems would be efficient for attaining maximum yield, uptake and fertilizer use efficiency under high P soils.

\section{References}

Agrawal M.M. and Verma B.S. (1998). Effect of phosphorus and sulphur on yield, N, P and S content and uptake by sunflower crop in Udic Ustochrepts. Annual Agricultural Research 19(4), 375-378.

Bogdanovic D., Ubavic M. and Cuvardic M. (1999). Effect of phosphorous fertilization on Zinc and Cadmium contents in soil and corn plants. Nutrient Cycling in Agroecosystems 54, 49-56.

Choudhary S.K. and Thakur R.B. (2007). Rational use of phosphorus in rice-wheat cropping system in Bihar plains. Oryza 44 (3), 282-284.

Deb D.L. (2009). Isotope aided research for enhanced use efficiency for $\mathrm{P}$ and $\mathrm{Zn}$. Journal of The Indian Society of Soil Science 57 (4), 412-421.

Gill M.A., Kanwal S., Aziz T and Rahmatullah. (2004). Differences in phosphorus-zinc interaction among sunflower (Helianthus annus L.), brassica (Brassica napus L.) and maize (Zea mays L.). Pakistan Journal of Agricultural Sciences 41, 1-2.

Giri B.H. and Venkata Reddy, P. (2005). Sulphur requirement and its use efficiency by soybean (Glycine max L.Merril) with different sources on Alfisols. Journal of Oilseeds Research 22 (2), 293297.

IAEA (1976). Tracer manual on crops and soils, technical report no 17, International Atomic Energy Agency, Vienna, Austria.

Jackson M.L. (1973). Soil Chemical Analysis Prentice Hall of India Pvt. Ltd., New Delhi.

Jat S.R., Patel B.J., Shivran A.C., Kuri B.R. and Jat G. (2013). Effect of phosphorus and sulphur levels on growth and yield of cowpea under rainfed conditions. Annals of Plant and Soil Research 15 (2), 114-117.

Kumar R., Sharma N.L., Tripathi P.N. and Singh R. (2002). Effect of zinc and phosphorus nutrition on rice (Oryza sativa). The Indian Journal of Agricultural Sciences 72 (12): 734-735.

Manchanda J.S., Singh A., and Dhaliwal S.S., (2012). Chemical pools of zinc and their availability to wheat in a Typic Haplustept as influenced by phosphorus and manganese fertilization. Journal of the Indian Society of Soil Science 60 (2), 156162.

Olsen S.R., Cole C.V., Watanabe F.S and Dean L.A. (1954). Estimation of available phosphorus in soil by extracting with sodium bicarbonate, USDA Circular 939, Washington. 
Oseni T.O. (2009). Growth and zinc uptake of sorghum and cowpea in response to phosphorus and zinc fertilization. World Journal of Agricultural Sciences $5(6), 670-674$.

Patel V.M., Patel C.L., Patel B.K., Patel A.M. and Patel D.D. (2012). Phosphorus management in rice-autumn sugarcane cropping sequence. Indian Journal of Agronomy 57 (4), 323-326.

Rao P.N., Singh A.P. and Singh B. (1989). Response of wheat-green gram-rice sequence to phosphorus and manganese. Current Agriculture 13 (1-2), 57-60.

Shaw K. (1959). Determination of organic carbon in soil and plant material. Journal of Soil Science 10, 316-326.

Singh, R.K., Sharma, R.K., Singh, M., Singh, R. and Singh, M. (1996). Effect of P, $\mathrm{Zn}, \mathrm{Fe}, \mathrm{CaCO}_{3}$ and farmyard manure on application on yield and quality of sunflower. Annals of Biology 12 (2), 203-208.

Subbaiah B.V. and Asija G.L. (1956). A rapid procedure for the determination of available nitrogen in soils. Current Science 25, 259-260.
Surendra Babu, P.,Venkata Reddy, P. and Sathe Arun. (2005). Phosphorus requirement and use efficiency by sunflower (Helianthus annus L.) in P-accumulated vertisols. Journal of Oilseeds Research 22 (2), 410413.

Surendra Babu P.,Venkata Reddy P., Sathe Arun and Madhavi, A. (2006). Phosphorus requirement and use efficiency by rice crop in high-P soils. In Annual reports of Radio Tracer Lab, Acharya NG Ranga Agricultural University, Hyderabad.

Walkley A. and Black C.A. (1934). Estimation of organic carbon by chromic acid titration method. Soil Science 37, 29-38

Wallace A., Mueller R.T. and Alexander G.V. (1977). Influence of phosphorus on zinc, iron, manganese, and copper uptake by plants. Soil Science 126 (6), 336-341.

Received: March 2016 Accepted: September 2016 